\title{
Hijacking ZIP codes: posttanscriptional regulation of CCN2 by nucleophosmin
}

\author{
Andrew Leask
}

Received: 19 November 2008 / Accepted: 5 February 2009/Published online: 18 February 2009

(C) The Author(s) 2009. This article is published with open access at Springerlink.com

\begin{abstract}
CCN2 (connective tissue growth factor [CTGF]/ hypertrophic chondrocyte-specific gene product 24 [Hcs24]) is regulated at the transcriptional and posttranscriptional level. For example, an element in the its $3^{\prime}$ untranslated region ( $3^{\prime}-\mathrm{UTR}$ ) of the CCN2 mRNA controls message stability in chondrocytes. In a recent study, Mukudai et al. (Mol Cell Biol 28:6134-6147, 2008) purified and identified a trans-factor protein binding to the minimal repressive cis element in the $3^{\prime}$-UTR of $\operatorname{ccn} 2$ mRNA and identify this protein as the multifunctional nucleolar phosphoprotein nucleophosmin (NPM) This commentary summarizes these observations.
\end{abstract}

\section{Keywords CTGF $\cdot$ CCN2 $\cdot$ UTR $\cdot$ Nucleophosmin}

CCN2 (connective tissue growth factor [CTGF]/hypertrophic chondrocyte-specific gene product 24 [Hcs24]) is a cysteine-rich secretory protein of 36 to $38 \mathrm{kDa}$ that has four distinct modules; that is, the insulin-like growth factorbinding protein-like, von Willebrand factor type $\mathrm{C}$ repeat, thrombospondin type 1 repeat, and $\mathrm{C}$-terminal modules (Leask and Abraham 2006). Although the regulation of CCN2 has been principally found to occur at the level of gene transcription (Grotendorst et al. 1996; Holmes et al. 2001;

This commentary is also available in the Newsletter section of the CCN Society website http://ccnsociety.com/

A. Leask

Canadian Institutes of Health Research Group in Skeletal

Development and Remodeling, Division of Oral Biology,

London, ON, Canada N6A 5C1

\section{A. Leask $(\square)$}

Department of Physiology and Pharmacology, Schulich School

of Medicine \& Dentistry, The University of Western Ontario,

London, ON, Canada N6A 5C1

e-mail: andrew.leask@schulich.uwo.ca
Leask et al. 2001), it has also been established that, inc chondrocytes, the $\mathrm{CCN} 2$ gene can also be regulated by elements in its $3^{\prime}$ untranslated region (3'-UTR) at posttranscriptional stages (Kondo et al. 2000). Indeed, a cis element in the 3'-UTR of chicken ccn2 mRNA plays an important role in CCN2 regulation in chondrocytes (Mukodai et al. 2005).

The 3' UTR has for quite some time been recognized as being responsible for positioning mRNAs in particular portions of the cell and hence controlling the location of RNA translation, especially in terms of the Drosophila oocyte (Macdonald and Struhl 1988; Macdonald et al. 1993). It is now accepted that the 3' UTR is generally required for placing mRNAs in subcellular compartments, and hence acts as a sort of ZIP code containing specific cis elements which can bind trans-acting factors which act to position mRNAs in cells. Such mechanisms involve the use of molecular motors such as dynein to shuttle mRNAs along microtubules (Epstein et al. 2000).

Nucleophosmin (NPM) is an abundantly expressed multifunctional nucleolar phosphoprotein. A unified mechanism for NPM's role in cell growth has recently been proposed; namely, that NPM directs the nuclear export of both 40S and 60S ribosomal subunits (Maggi et al. 2008). Transduction of NPM shuttling-defective mutants or loss of $\mathrm{Npm} 1$, inhibits nuclear export of both the 40S and 60S ribosomal subunits, reduces the available pool of cytoplasmic polysomes, and diminishes overall protein synthesis without affecting rRNA processing or ribosome assembly.

In a recent report, Mukudai et al. (2008) finally purified and identified this trans-factor protein binding the minimal repressive cis element in the $3^{\prime}$-UTR of $\operatorname{ccn} 2$ mRNA as NPM. With recombinant NPM protein, the authors were able to reproduce the posttranscriptional regulatory events in vitro that were observed during endochondral ossification in vivo. Alteration of nucleocytoplasmic shuttling of the trans factor 
was critical for the regulation of chicken ccn2 expression (Mukudai et al. 2008). The destabilization effect of NPM on ccn2 mRNA is more specific and robust in chondrocytes that in other cell types, suggesting that other proteins are in fact actually responsible for the stability of the CCN2 mRNA. These results suggest that NPM may normally act to shuttle RNAs and ribosomal subunits to the cytosol, possibly by interacting with cis acting sequences on the 3'-UTRs of RNA. However, NPM presumably has additional functions, and can possibly act to by bring in additional protein to RNAs.

To my knowledge, no study concerning the role of NPM in skeletal development has previously appeared in the literature; thus, the findings of Mukudai et al. (2008) appear to represent the first report of a novel NPM-mediated gene regulation system critical for proper chondrogenesis and endochondral ossification. The next goal of this laboratory is presumably to uncover the precise regulatory mechanism underlying the degradation of ccn 2 mRNA mediated by the interaction among its 3'-UTR and NPM, including any other factor(s) that needs to be identified.

Open Access This article is distributed under the terms of the Creative Commons Attribution Noncommercial License which permits any noncommercial use, distribution, and reproduction in any medium, provided the original author(s) and source are credited.

\section{References}

Epstein E, Sela-Brown A, Ringel I, Kilav R, King SM, Benashski SE, Yisraeli JK, Silver J, Naveh-Many T (2000) Dynein light chain binding to a 3 '-untranslated sequence mediates parathyroid hormone mRNA association with microtubules. J Clin Invest 105:505-512. doi:10.1172/JCI8557

Grotendorst GR, Okochi H, Hayashi N (1996) A novel transforming growth factor beta response element controls the expression of the connective tissue growth factor gene. Cell Growth Differ 7:469-480

Holmes A, Abraham DJ, Sa S, Shiwen X, Black CM, Leask A (2001) CTGF and SMADs, maintenance of scleroderma phenotype is independent of SMAD signaling. J Biol Chem 276:1059410601. doi:10.1074/jbc.M010149200

Kondo S, Kubota S, Eguchi T, Hattori T, Nakanishi T, Sugahara T, Takigawa M (2000) Characterization of a mouse ctgf 3 -UTR segment that mediates repressive regulation of gene expression. Biochem Biophys Res Commun 278:119-124. doi:10.1006/ bbrc. 2000.3780

Leask A, Abraham DJ (2006) All in the CCN family. J Cell Science 119:4803-4810

Leask A, Sa S, Holmes A, Shiwen X, Black CM, Abraham DJ (2001) The control of CTGF (ccn2) gene expression in normal and scleroderma fibroblasts. Mol Pathol 54:180-183. doi:10.1136/ mp.54.3.180

Macdonald PM, Struhl G (1988) cis-acting sequences responsible for anterior localization of bicoid mRNA in Drosophila embryos. Nature 336:595-598. doi:10.1038/336595a0

Macdonald PM, Kerr K, Smith JL, Leask A (1993) RNA regulatory element BLE1 directs the early steps of bicoid mRNA localization. Development 118:1233-1243

Maggi LB Jr, Kuchenruether M, Dadey DY, Schwope RM, Grisendi S, Townsend RR, Pandolfi PP, Weber JD (2008) Nucleophosmin serves as a rate-limiting nuclear export chaperone for the mammalian ribosome. Mol Cell Biol 28:7050-7065

Mukudai Y, Kubota S, Eguchi T, Kondo S, Nakao K, Takigawa M (2005) Regulation of chicken ccn2 gene by interaction between RNA cis element and putative trans-factor during differentiation of chondrocytes. J Biol Chem 280:3166-3177. doi:10.1074/jbc. M411632200

Mukudai Y, Kubota S, Kawaki H, Kondo S, Eguchi T, Sumiyoshi K, Ohgawara T, Shimo T, Takigawa M (2008) Posttranscriptional regulation of chicken ccn2 gene expression by nucleophosmin/ B23 during chondrocyte differentiation. Mol Cell Biol 28:61346147. doi:10.1128/MCB.00495-08 